\title{
Responses of Phytoplankton to Experimental Fertilization with Ammonium and Phosphate in an African Soda Lake
}

\author{
John M. Melack*, Peter Kilham, and Thomas R. Fisher \\ Department of Biological Sciences and Marine Science Institute, University of California, Santa Barbara, California 93106 \\ Division of Biological Sciences, University of Michigan, Ann Arbor, Michigan 48109 \\ Horn Point Environmental Laboratories, University of Maryland, Box 775, Cambridge, Maryland 21613, USA
}

\begin{abstract}
Summary. Phytoplankton abundance in tropical lakes is more often judged to be limited by nitrogen than phosphorus, but seldom does the evidence include controlled enrichments of natural populations. In January 1980 we performed the first experimental fertilization in an equatorial African soda lake, Lake Sonachi, a small, meromictic volcanic crater lake in Kenya. During our study the natural phytoplankton abundance was ca. $80 \mu \mathrm{g} \mathrm{chl} a / \mathrm{l}$, and the euphotic zone $\mathrm{PO}_{4}$ and $\mathrm{NH}_{4}$ concentrations were less than $0.5 \mu \mathrm{M}$. In the monimolimnion $\mathrm{PO}_{4}$ reached $180 \mu \mathrm{M}$ and $\mathrm{NH}_{4}$ reached $4,600 \mu \mathrm{M}$. Replicate polyethylene cylinders $\left(5 \mathrm{~m}\right.$ long, $1.2 \mathrm{~m}^{3}$ ) were enriched to attain $10 \mu \mathrm{M} \mathrm{PO}_{4}$ and $100 \mu \mathrm{M} \mathrm{NH}_{4}$. Phytoplankton responses were measured as chlorophyll, cell counts and particulate N, P and C. After two days, the chlorophyll increase in the $\mathrm{P}$ treatment was significantiy higher than the control $(P<0.01)$ while the $N$ treatment was not. After five days the molar N/P ratio of seston was the same in the $\mathrm{N}$ treatment and control (23) but only 6 in the P treatment. The molar N/P ratio of seston in an unenriched Lake Sonachi sample was 21 and in samples from Lakes Bogoria and Elmenteita, two shallow soda lakes in Kenya, the ratios were 12 and 70 respectively. We conclude that limitation of phytoplankton abundance by phosphorus can occur even in some tropical African soda lakes.
\end{abstract}

Phytoplankton abundance and production in tropical lakes is more often judged to be limited by inorganic nitrogen than phosphorus. For example, correspondence between depletion of nitrate and reduced algal productivity was observed in Lakes Victoria, Uganda (Talling 1966) and Lanao, Phillippines (Lewis 1974), and in reservoirs along the Nile River, Sudan (Prowse and Talling 1958, Talling and Rzoska 1967). Furthermore, Talling and Talling (1965) suggested nitrate limitation is likely in African lakes because nitrate concentrations are often very low. Conversely, high phosphate concentrations are not atypical of African lakes, especially the soda lakes (Talling and Talling 1965, Melack and Kilham 1974).

Phytoplankton growth actually depends on the rate of nutrient supply, and nutrient limitation is best documented by experimental manipulation of nutrient levels (e.g. Schindler and Fee 1974). The bioassays performed in African lakes usually implicate nitrogen or phosphorus or both as limiting phytoplankton growth (e.g. Evans 1961; Moss 1969; Robarts and Southall 1975, 1977; Viner 1973, 1977). Unfortunately, interpretation of

* Offprint requests to: J.M. Melack these results are confounded by the high nutrient concentrations and the small containers used (cf Gerhart and Likens 1975, Livingstone and Melack 1981). An alternative approach to assess phosphorus limitation with ${ }^{32} \mathrm{P}$ was applied by Peters and MacIntyre (1976). Turnover rates of ${ }^{32} \mathrm{P}_{-} \mathrm{PO}_{4}$ are expected to be rapid when phosphorus is in short supply and to be slow when supply is adequate. Among the five Kenyan lakes Peters and MacIntyre investigated, turnover rates were both very rapid and very slow.

Among tropical lakes, the African soda lakes are renowned for their extremely high productivity, algal abundances and apparent surplus of phosphate. Exceptions do occur, and Lakes Elmenteita and Sonachi (Naivasha Crater Lake) Kenya, had low $\mathrm{PO}_{4}-\mathrm{P}$ concentrations and rapid turnover rates of ${ }^{32} \mathrm{P}-\mathrm{PO}_{4}$ when Peters and MacIntyre (1976) sampled these two lakes. Furthermore, Melack (1981) described periods of relatively low photosynthetic rates and chlorophyll $a$ concentrations in these two lakes. Unfortunately, the nitrogen content and supply in African soda lakes is unknown, and no experimental manipulations of nutrient levels have been attempted.

In this paper we report analyses of the nitrogen, phosphorus and carbon content of three Kenya soda lakes (Lakes Sonachi, Elmenteita and Bogoria). In Lake Sonachi we performed an experimental enrichment with ammonium and phosphate within $1.2 \mathrm{~m}^{3}$ polyethylene cylinders to test the hypothesis that phosphorus may limit the phytoplankton abundance. Phytoplankton responses were measured as chlorophyll, cell counts and particulate $\mathrm{N}, \mathrm{P}$ and $\mathrm{C}$.

\section{Methods}

\section{Analytical Procedures}

Water and phytoplankton samples were collected at specific depths with an opaque, plastic, 2-liter Van Dorn sampler or as integrated samples with a weighted, clear plastic tube. Electrical conductance was measured with a conductivity bridge and standardized to $20^{\circ} \mathrm{C}$ with temperature coefficients determined with Lake Sonachi water. $\mathrm{pH}$ was measured with a portable, digital meter and combination electrode. Dissolved oxygen was determined with the Winkler method. Photosynthesis was measured as the difference in dissolved oxygen between transparent and opaque bottles.

Samples for dissolved nutrient analyses were filtered through pre-rinsed, Whatman (GFC) glass-fiber filters within one hour of collection. Soluble reactive phosphate was measured with the molybdenum blue-ascorbic acid method (Strickland and Parsons 1972). Because the $\mathrm{pH}$ of the reaction mixture was about 1 , 
silica interference did not occur. Nitrite was measured with the sulfanilamide method (Strickland and Parsons 1972) after lowering the $\mathrm{pH}$ to 3.9 with glacial acetic acid. Internal standards were used because color development was lower than in distilled water acidified to $\mathrm{pH}$ 3.9. Color blanks were often high. Further interference occurred at depths of $4 \mathrm{~m}$ and below in Lake Sonachi, and no reliable determinations could be made there. Hydrogen sulfide was present at $4 \mathrm{~m}$ and below, but an acidification and degassing trial did not eliminate the interference. Nitrate was reduced to nitrite in a cadmium-copper column (Strickland and Parsons 1972) and detected as nitrite with the sulfanilamide method. Internal standards were used, and indicated that column reduction efficiencies remained low (ca. 60\%). Ammonium was measured with the indophenol blue method (Strickland and Parsons 1972). Dilutions up to 1 to 100 were required below 4 meters to eliminate $\mathrm{H}_{2} \mathrm{~S}$ interference and to keep the concentrations within Beer's range.

Samples for particulate nitrogen, carbon and phosphorus were collected on ashed Whatman (GFC) glass fiber filters and were dried for storage. Nitrogen and carbon were determined with a Perkin-Elmer CHN analyzer. Phosphorus was measured after acid-persulfate digestion (Menzel and Corwin 1965) with the molybdenum blue-ascorbic acid method.

Subsamples of unfiltered water were sealed in glass ampoules and boiled to stop biological activity. These samples were analyzed for total phosphorus as described above for particulate phosphorus. Total inorganic carbon was measured with an infrared gas analyzer after acidification and degassing.

Chlorophyll $a$ was determined in $90 \%$ acetone extracts of seston collected on Whatman (GFC) glass fiber filters following homogenization and extraction at room temperature in the dark. Filters were stored frozen for as long as one week before analysis. The optical densities were read in a portable spectrophotometer (Bausch and Lomb Mini-20) with band-widths of $20 \mathrm{~nm}$. The ratio of optical densities of chlorophyll acetone extracts at 665 measured with a Perkin-Elmer-Hitachi Spectrophotometer (bandwith $1 \mathrm{~nm}$ ) to the optical densities measured with the Bausch and Lomb Mini-20 was 1.16. The optical densities were corrected by this factor and converted to concentrations of chlorophyll $a$ using a specific absorption coefficient of 89 (Golterman 1969).

Phytoplankton samples were preserved with $1 \mathrm{ml}$ of $40 \%$ formaldehyde per $20 \mathrm{ml}$ of lake water. One $\mathrm{ml}$ subsamples were allowed to settle in counting chambers and enumerated with a Leitz Diavert inverted microscope with phase contrast and oil immersion $(100 \times$ apochromatic objective, total magnification $1,250 \times)$. Abundances are reported for those species accounting for greater than $5 \%$ of the total number. Diatom identifications are based on Hustedt (1930) and Müller (1899). Identifications of the cyanobacteria and chlorophytes were made with Prescott (1962), Geitler (1932), Desikachary (1959) and Smith (1950). Monallantus salina (Eustigmatophyceae) is described in Antia et al (1975). Dr. Robert R.L. Guillard (Woods Hole Oceanographic Institution) provided cultures of Monallantus salina and Nannochloris atomus to aid our identifications.

Transparency was estimated with a $20 \mathrm{~cm}$, white Secchi disk. Attenuation of photosynthetically available irradiance (PAR, $400-700 \mathrm{~nm}$ ) was measured with a specially filtered, cosine corrected, silicon photodiode with an output expressed as $\mu$ einsteins $\mathrm{m}^{-2} \mathrm{~s}^{-1}$ ("quantum sensor", LiCor Corp.). Incident PAR was detected with another "quantum sensor" and recorded as daily totals with a portable integrator. A thermistor and Wheatstone bridge circuit with output readable to $0.2^{\circ} \mathrm{C}$ was used to measure the vertical distribution of temperature.
Nitrogen fixation was assayed as acetylene reduction in $100 \mathrm{ml}$ serum bottles. Time series and a range of acetylene concentrations were used. Gas samples were injected into vacutainers and analyzed with a Packard-Becker model 417 gas chromatograph after a delay of three months. The detection limit was $10^{-12}$ mole ethylene $1^{-1}$.

\section{Experimental Design}

Transparent cylinders, $1.2 \mathrm{~m}^{3}$ in volume and $5 \mathrm{~m}$ long, were constructed from sheets of polyethylene. Hoops at $1 \mathrm{~m}$ intervals prevented collapse of the cylinders, and a square wooden collar attached at the top provided floatation. Polyethylene extended $10 \mathrm{~cm}$ above the wooden collar to reduce waves breaking into the cylinders; the largest waves in Lake Sonachi are $10 \mathrm{~cm}$. The cylinder had no bottoms but extended $1 \mathrm{~m}$ into the chemocline; vertical transport in the chemocline is due primarily to molecular diffusion.

Six cylinders in racks of three each were deployed in the middle of Lake Sonachi. Two experimental enrichments with ammonium and phosphate were performed. Each experiment had two controls, one on each rack. In the first experiment two cylinders were enriched with ammonium and two with phosphate. In the second experiment two cylinders were enriched with ammonium and phosphate and one each with ammonium or phosphate. In all ammonium fertilizations a solution of $\mathrm{NH}_{4} \mathrm{Cl}$ was added to attain a final concentration of $100 \mu \mathrm{M}$ $\mathrm{NH}_{4}$, a loading equivalent to $7 \mathrm{~g} \mathrm{~N}$ per $\mathrm{m}^{2}$. In all phosphate fertilizations a solution of $\mathrm{Na}_{2} \mathrm{HPO}_{4}$ was added to attain a final concentration of $10 \mu \mathrm{MPO}_{4}$, a loading equivalent to $1.56 \mathrm{~g} \mathrm{P}$ per $\mathrm{m}^{2}$. The nutrients were added by filling a flexible plastic tube and dispersing the solution throughout the cylinder.

Collections were made at the time of the fertilization and after 2, 5 or 6 and 8 days, as an integrated sample of each cylinder. The samples were analyzed for chlorophyll $a$, particulate $N, C$ and $P$, total $P$, and species composition and abundance. Incident PAR was recorded during the experiments.

Potential but minor problems with cylinders include deformation of their flexible sides that change their volume, birds sitting on the wooden collars and defecating into the cylinders and some wave breaking into the cylinders. Altered vertical mixing inside the cylinders in comparison to the open lake could allow increased phytoplankton sinking and may augment or retard vertical diffusion of nutrients from the chemocline. Temperature profiles measured inside and outside the cylinders during midday were similar (but see Boyce 1974). Growth of periphyton on the polyethylene became serious after 6 days and contributed to elevated chlorophyll values in the control cylinders (see below).

Experiments and measurements were made at Lake Sonachi during December 1979 and January 1980. Lakes Elmenteita and Bogoria were sampled in January 1980.

\section{Descriptions of the Lakes and Their Basins}

Lakes Sonachi, Elmenteita and Bogoria lie in closed basins at moderate altitude within one degree of the equator (Table 1). The regional climate is warm and semi-arid with rains typically in April, May and November as intense, local storms. Perennial rivers flowing from the neighboring highlands enter the north ends of Lakes Elmenteita and Bogoria; no streams enter Lake Sonachi.

The water temperatures are warm (ca. $15-30^{\circ} \mathrm{C}$ ), and daily changes are similar to seasonal variations (Melack 1976). A diel cycle of stratification and mixing of temperature and dissolved 
Table 1. Geographic and morphometric features of three Kenya soda lakes; Altitude, $\mathrm{m}$; area, $\mathrm{Km}^{2}$; $\mathrm{Zmax}$, maximum depth, $\mathrm{m}$

\begin{tabular}{llccl}
\hline Lake & Location & Altitude & Area & Zmax \\
\hline Sonachi & $0^{\circ} 47^{\prime} \mathrm{S} 36^{\circ} 16^{\prime} \mathrm{E}$ & 1,891 & 0.18 & 8 \\
Elmenteita & $0^{\circ} 27^{\prime} \mathrm{S} 36^{\circ} 15^{\circ} \mathrm{E}$ & 1,776 & 20 & 2 \\
Bogoria & $0^{\circ} 15^{\prime} \mathrm{N} 36^{\circ} 06^{\prime} \mathrm{E}$ & 963 & 33 & 9 \\
\hline
\end{tabular}

oxygen occurs throughout Lakes Elmenteita and Bogoria and in the $4 \mathrm{~m}$ mixolimnion of meromictic Lake Sonachi (Melack 1976). The monimolimnion of Lake Sonachi is anoxic (Fig. 1) and contains $\mathrm{H}_{2} \mathrm{~S}$ (MacIntyre 1981). In these alkaline, saline lakes the $\mathrm{pH}$ is above 9.5 and the electrical conductance is above $4.5 \mathrm{mS} \mathrm{cm}^{-1}$ (Table 2). Sodium is the principal cation, and silica and fluoride concentrations are high (Hecky and Kilham 1973). The three lakes are turbid (Table 2), and phytoplankton usually account for most of the attenuation.

Lake Sonachi (also called Naivasha Crater Lake) lies in a volcanic crater formed by an agglomerate (Thompson and Dodson 1963) that encloses an area of 84 ha. A crater rim $30 \mathrm{~m}$ to $115 \mathrm{~m}$ above the water and a shoreline fringe of Acacia xanthophloea shelter the lake from high winds. The inside slopes of the crater are vegetated with dense bush including Tarchonanthus camphoratus on the drier pitches and Rhus natalensis and Pluchea ovalis near the lake. After a six year period of declining water levels, rainfall in the period from 1977 to 1979 was sufficient to raise the level $3 \mathrm{~m}$. During the period from 1971 through 1979 the chemical stability, the amount of work required to mix a chemically stratified lake to uniform concentration, ranged from $700 \mathrm{ergs} \mathrm{cm}^{-2}$ (November 1976) to 200,300 ergs $\mathrm{cm}^{-2}$ (December 1979; MacIntyre 1981). The maximum depth in January 1980 was about $8 \mathrm{~m}$. This increase in level formed a band of dead or dying $A$. xanthophloea that extends $5-20 \mathrm{~m}$ into the lake.

Lakes Elmenteita and Bogoria are broad, shallow lakes lying in tectonic basins associated with fault scarps. Their water levels fluctuate considerably in response to wet and dry seasons and annual trends in rainfall. During the period from 1973-1974 major changes in the biological communities occurred in association with an abnormally dry period. Additional descriptions of these lakes and their drainage basins are provided in Melack (1976, 1981), Melack and Kilham (1974), Livingstone and Melack (1981) and the Kenya Government (1970) atlas.

\section{Results and Discussion}

\section{Nutrients and Phytoplankton}

Chemical conditions in the euphotic regions of Lakes Sonachi, Elmenteita and Bogoria are sumarized in Table 2. With the exception of the high orthophosphate value in Lake Bogoria, the dissolved inorganic nitrogen and phosphorus concentrations are very low $(<0.5 \mu \mathrm{M})$. Dissolved inorganic carbon is high. Particulate organic phosphorus, nitrogen and carbon and chlorophyll $a$ are all very high and are typical of eutrophic or hypereutrophic waters.

Ammonium and orthophosphate concentrations reached very high values in the monimolimnion of Lake Sonachi (Fig. 2); similar values were reported by Melack (1981) for May 1974. Because the orthophosphate increase was less steep and began deeper than the ammonium gradient, the potential for vertical diffusion of ammonium was substantially higher than that for

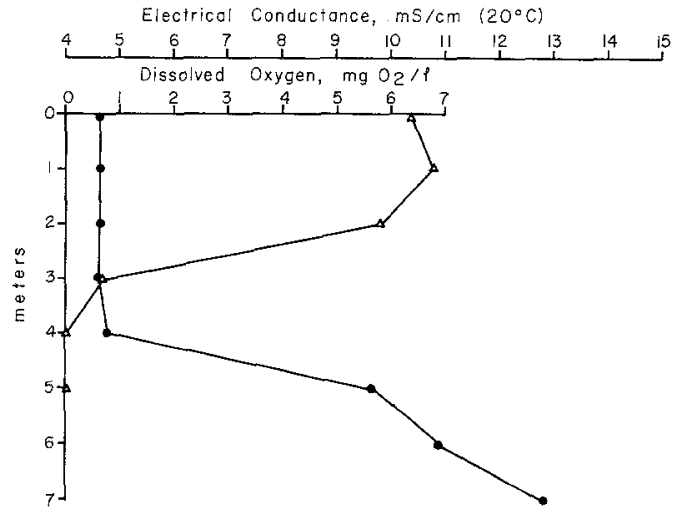

Fig. 1. Vertical profiles of dissolved oxygen $(\triangle, 1 \mathrm{Jan} 80)$ and electrical conductance $(\bullet, 26 \mathrm{Dec} 79)$ in Lake Sonachi

Table 2. Limnological conditions in euphotic region of Lakes Sonachi, Elmenteita (3 January 1980) and Bogoria (11 January 1980). Abbreviations: PAR, photosynthetically available irradiance, POC, particulate organic carbon, $\mathrm{PN}$, particulate organic nitrogen, $\mathrm{PP}$, particulate organic phosphorus, DIC, dissolved inorganic carbon, SRP, soluble reactive phosphorus

\begin{tabular}{|c|c|c|c|}
\hline & Sonachi ${ }^{1}$ & Elmenteita $^{2}$ & Bogoria $^{3}$ \\
\hline $\begin{array}{l}\text { Conductance } \\
\left(\mathrm{mS} / \mathrm{cm}, 20^{\circ} \mathrm{C}\right)\end{array}$ & $4.65^{\mathrm{a}}$ & 18.8 & 71 \\
\hline $\mathrm{pH}$ & $9.6^{\mathrm{a}}$ & 10.1 & 10.4 \\
\hline Secchi $(\mathrm{cm})$ & $50-55^{\mathrm{b}}$ & 15 & 60 \\
\hline $\begin{array}{l}\text { PAR attenuation } \\
(\ln / \mathrm{m})\end{array}$ & $3.1^{\mathrm{c}}$ & 9.2 & - \\
\hline $\begin{array}{l}\text { Chlorophyll } a \\
(\mu \mathrm{g} / 1)\end{array}$ & $68-83^{d}$ & 420 & 90 \\
\hline $\mathrm{POC}(\mu \mathrm{M})$ & $712^{\mathrm{e}}$ & 5,040 & - \\
\hline $\operatorname{PN}(\mu \mathrm{M})$ & $73^{e}$ & 654 & 65 \\
\hline total $\mathrm{P}(\mu \mathrm{M})$ & $4.7^{\mathrm{e}}$ & 19.0 & - \\
\hline $\mathrm{PP}(\mu \mathrm{M})$ & $3.6^{\mathrm{e}}$ & 9.3 & 5.5 \\
\hline $\mathrm{DIC}(\mathrm{mM})$ & $39^{\mathrm{e}}$ & 78 & - \\
\hline $\operatorname{SRP}(\mu \mathrm{M})$ & $\leqq 0.3^{\mathrm{f}}$ & $<0.5$ & 48 \\
\hline $\mathrm{NH}_{4}+\mathrm{NH}_{3}(\mu \mathrm{M})$ & $<0.5^{\mathrm{f}}$ & $\leqq 0.5$ & $\leqq 0.2$ \\
\hline $\mathrm{NO}_{2}(\mu \mathrm{M})$ & $<0.4^{f}$ & $<0.4$ & $<0.4$ \\
\hline $\mathrm{NO}_{3}(\mu \mathrm{M})$ & $<0.4^{\mathrm{f}}$ & $<0.4$ & $<0.4$ \\
\hline POC/PN & 9.8 & 7.7 & - \\
\hline $\mathrm{POC} / \mathrm{PP}$ & 198 & 542 & - \\
\hline $\mathrm{PN} / \mathrm{PP}$ & 21 & 70 & 12 \\
\hline
\end{tabular}

1 Mid lake station

2 Station $400 \mathrm{~m}$ off north shore

3 Station $200 \mathrm{~m}$ off middle of west shore

a, 26 Dec 79; b, 13 Dec 79-12 Jan 80 (5 days); c 1 and 6 Jan 80; d, 26 Dec 79-12 Jan 80 (5 days); e, 4 Jan 80; f, 26 and 29 Dec 79

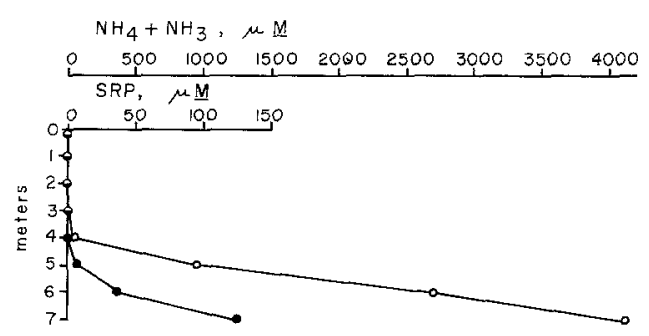

Fig. 2. Vertical profiles of ammonia ( $O$ ) and soluble reactive phosphate $(\mathrm{SRP}$,$) in Lake Sonachi, 1$ Jan 80 
phosphorus. However, because wind mixing is normally weak and the chemical stability strong (MacIntyre 1981), it is unlikely that the monimolimnion is usually a large source of either nitrogen or phosphorus to the euphotic region. Two exceptions have been observed. The first occurred in July and August 1974 when the transparency of the lake doubled and a bloom of photosynthetic sulfur bacteria developed within the upper chemocline (Melack 1976). A second took place in early November 1976 when the chemical stability was very low and mean wind speeds were high (ca. $8 \mathrm{~m} \mathrm{~s}^{-1}$ ). Within the subsequent two weeks a bloom of phytoplankton developed.

The photosynthetic rates of the phytoplankton in Lake Sonachi on 6 January 1980 (incubated 1130-1600) were modest for an African soda lake, but similar to the rates reported by Melack (1981) for Lake Sonachi in 1973 and 1974. For water collected at $20 \mathrm{~cm}$ and suspended at $10,30,60$ and $110 \mathrm{~cm}$ maximal gross photosynthesis was $630 \mathrm{mg} \mathrm{O} \mathrm{O}^{-3} \mathrm{~h}^{-1}$ or $8.3 \mathrm{mg} \mathrm{O}_{2}$ (mg chl a) ${ }^{-1} \mathrm{~h}^{-1}$; maximal net photosynthesis was $410 \mathrm{mg} \mathrm{O}_{2} \mathrm{~m}^{-3}$ $\mathrm{h}^{-1}$ or $5.4 \mathrm{mg} \mathrm{O}_{2}(\mathrm{mg} \mathrm{chl} a)^{-1} \mathrm{~h}^{-1}$, and respiration averaged $190 \mathrm{mg} \mathrm{O}_{2} \mathrm{~m}^{-3} \mathrm{~h}^{-1}$ or $2.5 \mathrm{mg} \mathrm{O}$ (mg chl $\left.a\right)^{-1} \mathrm{~h}^{-1}$. Similar values were obtained for water collected at $2 \mathrm{~m}$ and suspended at the same four depths.

Five species of phytoplankton accounted for $95 \%$ of the algae in Lake Sonachi: Synechococcus bacillaris Butcher, Synechocystis aquatilis Sauv., Spirulina laxissima G.S. West, Monallantus salina Bourrelly and Nannochloris atomus Butcher. Common species in Lake Elmenteita included Navicula el kab O. Mull., Synechocystis aquatilus (?), Spirulina sp. (trichome diameter $1 \mu$, coil length $3 \mu$ ) and Nannochloris sp. (?); less common were Nitzschia sp. cf. latens Hust. and Spirulina platensis (Norst.) Geitl. Two species dominated Lake Bogoria, Spirulina platensis was most common and a Chlamydomonas $\mathrm{sp}$. was subdominant.

Kilham (1981) found exceptionally high numbers of pelagic bacteria in Lakes Sonachi, Elmenteita and Bogoria. In formalin preserved samples collected in January 1980 and counted with the acridine orange method he observed concentrations of $10^{7}-10^{8}$ bacteria $\mathrm{ml}^{-1}$. Such high numbers probably indicate very rapid mineralization of organic matter in these lakes.

Several kinds of evidence, in part derived from the above data, imply that phosphorus deficiency is likely in Lake Sonachi and especially likely in Lake Elmenteita. The sestonic ratios of $\mathrm{N} / \mathrm{P}, \mathrm{C} / \mathrm{N}$ and $\mathrm{C} / \mathrm{P}$ are similar to those of phytoplankton experiencing phosphorus not nitrogen limitation (Lehman et al. 1975, Healey and Hendzel 1980). Nitrogen fixation by the plankton was not detected, and this is consistent with the hypothesis that there was a sufficient nitrogen supply. Furthermore, the $\mathrm{N} / \mathrm{P}$ ratio of the potential fluxes of ammonium and phosphate from the monimolimnion to the mixolimnion of Lake Sonachi is likely to be greater than 100 . This ratio was derived from the gradients in Figure 2 and a molecular eddy diffusivity coefficient for both solutes. Although not specific for phosphorus, the low photosynthetic capacity $\left(\mathrm{mg} \mathrm{O}_{2}(\mathrm{mg} \mathrm{chl} a)^{-1}\right)$ in Lake Sonachi is indicative of nutrient deficiency.

In contrast, Lake Bogoria has exceptionally high orthophosphate concentrations and a sestonic N/P ratio indicative of adequate supply of phosphorus and possible nitrogen deficiency. High phosphate concentrations have also been reported in Lakes Simbi (Melack 1979) and Aranguadi (Talling et al. 1973) at times with high Spirulina platensis numbers. Inorganic nitrogen concentrations during such times are less certain. While Melack (1979) reported ammonium values $\leqq 2 \mu \mathrm{M}$ in the euphotic zone of Lake Simbi, ammonium values as high as $25 \mu \mathrm{M}$ occurred in Lake Nakuru during a period with large numbers of $S$. platensis (December 1976, Melack unpublished). No nitrate or nitrite data other than those reported here are available. Nitrogen fixation was not detected in samples of plankton collected from Lake Bogoria in January 1980. Furthermore, attempts to detect nitrogen fixation as acetylene reduction with axenic cultures of Spirulina platensis, nitrogen replete and depleted and under oxic and anoxic conditions, were unsuccessful (Melack and Rhodes, unpublished).

\section{Nutrient Enrichment Experiments}

To directly test the hypothesis that phosphorus supply may limit the abundance of phytoplankton in Lake Sonachi we performed an experimental enrichment with ammonium and phosphorus in cylinders suspended in the lake. The results of these experiments (Fig. 3, Tables 3 and 4) support this hypothesis and also indicate some response to ammonium addition. The null hypothesis that the differences expressed as changes in chlorophyll $a$ between controls and enrichments can be attributed to chance can be rejected for the phosphate treatments at the 0.01 level after 2 days. The null hypothesis can also be rejected at the 0.05 level after 5 or 6 days for treatments where phosphate and ammonium were added singly; it cannot be rejected for the ammonium enrichments after only 2 days. After two days the ammonium plus phosphate treatment was higher than the control
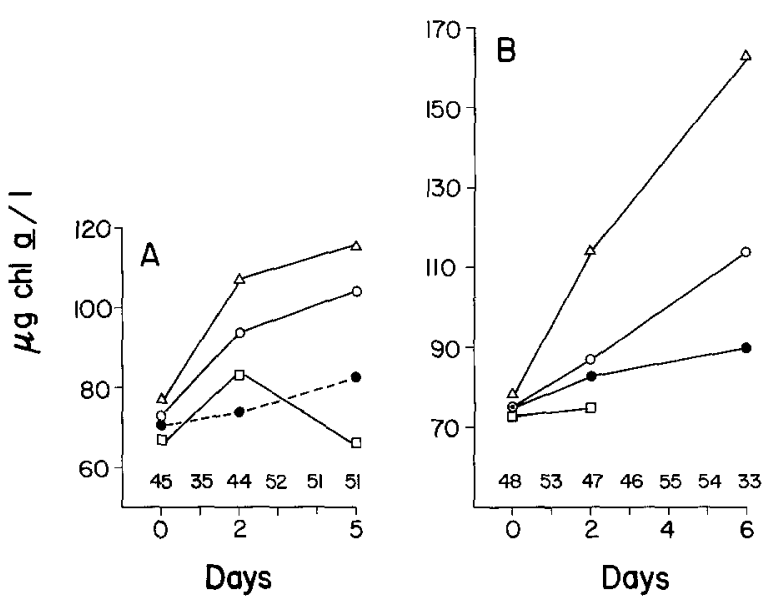

Fig. 3. Mean chlorophyll $a$ changes during two experimental enrichments in Lake Sonachi: Control $(\bullet)$, ammonium addition $(0)$, phosphate addition $(\triangle)$, open lake near cylinders $(\square)$. A, 30 December 1979 - 4 January 1980; B, 6 January 1980-12 January 1980 . Numbers along bottom of figure are total daily irradiances expressed as einsteins $\mathrm{m}^{-2} \mathrm{~d}^{-1}$ of photosynthetically available irradiance

Table 3. Changes in chlorophyll a (Chl, $\mu \mathrm{g}$ chl $\left.a \mathrm{l}^{-1} \mathrm{~d}^{-1}\right)$ after enrichments with ammonium $(\mathrm{N})$ and phosphate $(\mathrm{P})$. Combined results of two experiments assuming homogeneity of variances. $\mathrm{Sd}$ is one standard deviation of changes in chlorophyll; $\mathrm{n}$ is number of replicates. Significance levels based on two way ANOVA: **0.01 Level; *0.05 level

\begin{tabular}{lcccccccc}
\hline \multirow{2}{*}{ Treatment } & \multicolumn{2}{c}{ After 2 days } & & \multicolumn{3}{c}{ After 5 or 6 days } \\
\cline { 2 - 3 } \cline { 7 - 8 } & Chl & sd & $n$ & & Chl & sd & $n$ \\
\hline Control & 2.9 & 5.1 & 4 & & 2.5 & 1.4 & 3 \\
$\mathrm{~N}$ & 8.8 & 2.8 & 3 & & $7.2^{*}$ & 0.9 & 2 \\
$\mathrm{P}$ & $16.3^{* *}$ & 2.1 & 3 & & $11.0^{*}$ & 4.5 & 2 \\
$\mathrm{~N}+\mathrm{P}$ & 13.3 & 6.0 & 2 & & 2.1 & 0.1 & 2 \\
\hline
\end{tabular}


Table 4. Chlorophyll a (Chl $\left.a, \mu \mathrm{gl}^{-1}\right)$ and particulate organic phosphorus $(\mathrm{PP})$, nitrogen $(\mathrm{PN})$ and carbon (POC) concentrations $(\mu \mathrm{M})$ and molar ratios in one set of experimental cylinders in Lake Sonachi five days after enrichment with ammonium $(\mathrm{N})$ and phosphate (P) (see text for details). Italicized values are notably different from the controls. Standard deviations are in parenthesis; two relicates were analyzed for these values

\begin{tabular}{lccc}
\hline & $\mathrm{N}$ & $\mathrm{P}$ & Control \\
\hline Chl $a$ & 104 & 115 & $83(10)$ \\
PP & 5.0 & $19.8(0.4)$ & $4.5(1.4)$ \\
PN & $119(3)$ & $124(1)$ & $103(1)$ \\
POC & $768(26)$ & $756(9)$ & $649(1)$ \\
POC/PP & 154 & 38.2 & 144 \\
POC/PN & 6.5 & 6.1 & 6.3 \\
PN/PP & 23.8 & 6.3 & 22.9 \\
\hline
\end{tabular}

at only the 0.1 level, and after six days an unexpected and unexplained decrease in the change in chlorophyll concentration had occurred.

Some shifts in phytoplankton species composition occurred during these experiments. The largest change was the 2 fold increase in the relative abundance of $N$. atomus in the phosphorus treatment and the 3-4 fold increase in the nitrogen treatment and control. A slight reduction in the relative abundance of $M$. salina was observed in all the cylinders. S. laxissima maintained the same relative abundance in the treatments but decreased one half in the control. No shift occurred for $S$. bacillaris, and the abundance of $S$. aquatilis was too low to detect changes in relative abundance. If longer experiments had been possible, larger shifts in species composition would be likely (eg. Kilham and Kilham 1978).

When the responses five days after fertilization are expressed in terms of particulate organic carbon, nitrogen and phosphorus, the most pronounced effect is the increase in particulate phosphorus in the cylinder fertilized with phosphate. This large increase in particulate phosphorus probably represents luxury uptake. Furthermore, the N/P and C/P ratios in the cylinder fertilized with phosphate are indicative of no phosphorus deficiency, and the $\mathrm{C} / \mathrm{N}$ ratio does not indicate nitrogen deficiency (Healy and Hendzel 1980). These three ratios in the nitrogen treatment and control were similar and indicated slight phosphorus deficiency and no nitrogen limitation. However, the particulate organic carbon and nitrogen increased to similar levels in the phosphate and ammonium additions and both were significantly above the controls and lake (Table 1).

Our observation that phosphorus is more limiting to phytoplankton abundane than ammonium in two African soda lakes indicates that it is premature to claim that most tropical lakes are limited by nitrogen. In Lakes Sonachi and Elmenteita, although both inorganic nitrogen and phosphorus were nearly undetectable, particulate $\mathrm{N} / \mathrm{P}$ ratios were greater than 20 , no nitrogen fixation was detectable, and experimental phosphate additions to large volume cylinders in Lake Sonachi produced the greater effect on algal abundance. In contrast, Lake Bogoria had large excesses of dissolved phosphate, and had particulate $\mathrm{N} / \mathrm{P}$ ratios of 12 , both of which indicate that nitrogen is in shorter supply than phosphorus. We suggest that the phytoplankton of tropical lakes are just as likely to be limited by any given nutrient (i.e. phosphorus, nitrogen, silica, iron, etc.) than the phytoplankton of lakes elsewhere in the world.

Acknowledgements. Financial support was provided from U.S. National Science Foundation grants DEB 78-23642 to T.R.F. and J.M.M. and SPS-79-14932 to P.K. and N.S.F. international travel awards to J.M.M. and P.K. Research permission was granted by the Permanent Secretary to the Office of the President, Republic of Kenya, and access to the lake was given by the manager of Ndabibi, Ltd. We thank R. Mennell, J.J. Gaudet, S. Njuguna and J. Kalff for field assistance, L. Yarbro and P. Carlson for laboratory analyses of particulate phosphorus and ethylene and G.G. Ganf for helpful discussion.

\section{References}

Antia NJ, Bisalputra T, Cheng Y, Kalley JP (1975) Pigment and cytological evidence for reclassification of Nannochloris oculata and Monallantus salina in the Eustigmatophyceae. J Phycol 11:339-343

Boyce FM (1974) Mixing within experimental enclosures: a cautionary note on the limnocorral. J Fish Res Board Can 31:1400-1405

Desikachary TV (1959) Cyanophyta. Indian Council of Agricultural Research New Delhi. p 680

Evans JH (1961) Growth of Lake Victoria phytoplankton in enriched cultures. Nature 189:417

Geitler L (1932) Cyanophyceae. In: L Rabenhorst's Kryptogamen Flora von Deutschland, Österreich und der Schweiz Vol 14. Akademische Verlagsgesellschaft mbH, Leipzig p 1-1196

Gerhart DZ, Likens GE (1975) Enrichment experiments for determining nutrient limitation: four methods compared. Limnol Oceanogr $20: 649-653$

Golterman HL (ed) (1969) Methods for chemical analysis of fresh waters. IBP Handbook No 8. Blackwell Scientific Publications Oxford. $\mathrm{p} 166$

Healey FP, Hendzel LL (1980) Physiological indicators of nutrient deficiency in lake phytoplankton. Can J Fish Aquat Sci 37:442-453

Hecky RE, Kilham P (1973) Diatoms in alkaline, saline lakes: ecology and geochemical implications. Limnol Oceanogr 18:53-71

Hustedt F (1930) Bacillariophyta (Die Süßwasser-flora mitteleuropas vol X). G Fisher Jena. p 466

Kenya Government (1970) National atlas of Kenya. Survey of Kenya, Nairobi. p 103

Kilham P (1981) Pelagic bacteria: extreme abundance in African saline lakes. Naturwissenschaften 67:380-381

Kilham SS, Kilham P (1978) Natural community bioassays: predictions of results based on nutrient physiology and competition. Verh Internat Verein Limnol 20:68-74

Lehman JT, Botkin DB, Likens GE (1975) The assumptions and rationales of a computer model of phytoplankton dynamics. Limnol Oceanogr 20:343-364

Lewis WM Jr (1974) Primary production in the plankton community of a tropical lake. Ecol Monogr 44:377-409

Livingstone DA, Melack JM (1981) Some lakes of subsaharan Africa. In: FB Taub (ed), Lake and reservoir ecosystems. Elsevier Scientific Publ Co Amsterdam. In press

MacIntyre S (1981) Stratification and mixing in shallow tropical African lakes. PhD Thesis Duke Univ Durham NC. p 338

Melack JM (1976) Limnology and dynamics of phytoplankton in equatorial African lakes. PhD Thesis Duke Univ Durham NC p 453

Melack JM (1979) Photosynthesis and growth of Spirulina platensis (Cyanophyta) in an equatorial lake (Lake Simbi, Kenya). Limnol Oceanogr 24:753-760

Melack JM (1981) Photosynthetic activity of phytoplankton in tropical African soda lakes. In: WD Williams (ed). Proc First Internat Sympt Athallassic (Inland) Salt Lakes. Hydrobiologia 81:71-85

Melack JM, Kilham P (1974) Photosynthetic rates of phytoplankton in East African alkaline, saline lakes. Limnol Oceanogr 19:743-755

Menzel DW, Corwin N (1965) The measurement of total phosphorus in seawater based on the liberation of organically bound fractions by persulfate oxidation. Limnol Oceanogr 10:280-282

Moss B (1969) Limitation of algal growth in some central African waters. Limnol. Oceanogr 14:591-601

Müller O (1899) Bacillareen aus den Natronthalen von El Kab (oberAegypten). Hedwigia $38: 274-321$

Peters RH, MacIntyre S (1976) Orthophosphate turnover in East African lakes. Oecologia (Ber1) 25:313-319 
Prescott GW (1962) Algae of the western Great Lakes Area. Wm G Brown Co Publ Dubuque, Iowa $p 977$

Prowse GA, Talling JF (1958) The seasonal growth and succession of plankton algae in the White Nile. Limnol Oceanogr 3:223-238

Robarts RB, Southall GC (1975) Algal bioassays of two tropical Rhodesian reservoirs. Acta Hydrochim Hydrobiol 3:369-377

Robarts RB, Southall GC (1977) Nutrient limitation of phytoplankton growth in seven tropical man-made lakes, with special reference to Lake Mcllwaine, Rhodesia. Arch Hydrobiol 79:1-35

Schindler DW, Fee EJ (1974) Experimental Lakes Area: whole lake experiments in eutrophication. J Fish Res Board Can 31:937-953

Smith GM (1950) The freshwater algae of the United States. McGrawHill Book Co Inc New York. p 719

Strickland JDH, Parsons TR (1972) A practical handbook of seawater analysis. Fish Res Board Can Bull 167 (2nd ed). p 310

Talling JF (1966) The annual cycle of stratification and phytoplankton growth in Lake Victoria, East Africa. Int Revue ges Hydrobiol $51: 545-621$
Talling JF, Talling IB (1965) The chemical composition of African lake water. Int Revue ges Hydrobiol 50:421-463

Talling JF, Rzoska J (1967) The development of plankton in relation to hydrological regime in the Blue Nile. J Ecol 55;637-662

Talling JF, Wood RB, Prosser MV, Baxter RM (1973) The upper limit photosynthetic productivity by phytoplankton: evidence from Ethiopian soda lakes. Freshwater Biol 3:53-76

Thompson AO, Dodson RG (1963) Geology of the Naivasha area. Geological Survey of Kenya Report No 55. Goverment Printer Nairobi. $\mathrm{p} 80$

Viner $A B$ (1973) Responses of a mixed phytoplankton population to nutrient enrichments with ammonia and phosphate, and some associated ecological implication. Proc R Soc Lond B 183:351-370 Viner AB (1977) Relationships of nitrogen and phosphorus to a tropical phytoplankton population. Hydrobiologia 52:815-196

Received October 25, 1981 